IRA-International Journal of Management \&

Social Sciences

ISSN 2455-2267; Vol.09, Issue 02 (November 2017)

Pg. no. 47-54

Institute of Research Advances

http://research-advances.org/index.php/RAJMSS

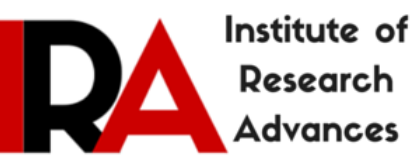

\title{
Growth of Transport Sector in Karnataka: An Analysis
}

\author{
Krishnappa $^{1}$ \& T. Rajendra Prasad ${ }^{2}$ \\ ${ }^{1}$ Research Scholar, Department of Economics, Bangalore University, Bangalore, India. \\ ${ }^{2}$ Professor \& Chairman, Department of Economics, Bangalore University, Bangalore, India.
}

Type of Review: Peer Reviewed.

DOI: http://dx.doi.org/10.21013/jmss.v9.v2.p1

\section{How to cite this paper:}

Krishnappa, Prasad, T.R. (2017). Growth of Transport Sector in Karnataka: An Analysis. IRAInternational Journal of Management \& Social Sciences (ISSN 2455-2267), 9(2), 47-54. doi:http://dx.doi.org/10.21013/jmss.v9.n2.p1

(C) Institute of Research Advances.

(cc) BY-No
This work is licensed under a Creative Commons Attribution-Non Commercial 4.0 International
License subject to proper citation to the publication source of the work.

License subject to proper citation to the publication source of the work.

Disclaimer: The scholarly papers as reviewed and published by the Institute of Research Advances (IRA) are the views and opinions of their respective authors and are not the views or opinions of the IRA. The IRA disclaims of any harm or loss caused due to the published content to any party.

Institute of Research Advances is an institutional publisher member of Publishers Inter Linking Association Inc. (PILA-CrossRef), USA. The institute is an institutional signatory to the Budapest Open Access Initiative, Hungary advocating the open access of scientific and scholarly knowledge. The Institute is a registered content provider under Open Access Initiative Protocol for Metadata Harvesting (OAI-PMH).

The journal is indexed \& included in WorldCat Discovery Service (USA), CrossRef Metadata Search (USA), WorldCat (USA), OCLC (USA), Open J-Gate (India), EZB (Germany) Scilit (Switzerland), Airiti (China), Bielefeld Academic Search Engine (BASE) of Bielefeld University, Germany, PKP Index of Simon Fraser University, Canada. 


\begin{abstract}
The significance of urban transport in India plays a major role in the reduction of poverty. Services and manufacturing industries particularly concentrate around major urban areas, and require efficient and reliable urban transport systems to move workers and connect production facilities to the logistics chain. In this regard due to the growth of IT sector in Bangalore, there has been an ongoing infrastructure investment in urban roads. With this background the present paper seeks to examine the growth and development of transport sector in Karnataka with special reference to Bangalore.
\end{abstract}

Keywords: Developmental Studies; Transport; Logistics; Economics

\title{
INTRODUCTION
}

Transport system is essential not only for the growth of economic infrastructurebut also it helps in the development of trade, commerce and industry. Transport system of a country refers to the different means which carry men and material from one place to another. Transport system helps to minimize the travel time and facilitates the mobility of goods and services from producers to consumers. In this way it helps in removing regional inequalities. Development of transport facilities is also essential for surviving and tapping of natural resources.

There are three schools of thought about the role of transportation in economic development. First one is "Balance growth" approach which maintains that all sectors of economy must grow in tandem otherwise, there will be bottlenecks curtailing progress. Second one is "Leading sector"approach which says that transport capacity must be created in anticipation of demand as there is a long gestation period before one could reap the benefits of investments in the transportation sector. Third is the "Induced sector" approach which argues that, there is always a mismatch between demand and supply of transportation requirements because of the dynamics of the growth process.

Modes of Transportare air, rail, road, water, cable, pipeline, and space. Vehicles traveling include automobiles, bicycles, buses, trains, trucks, people, helicopters, and aircraft. The ownership of transport industry can be either public or private, depending on the country and mode. Transport demand is more with the increase of population and economic growth. India's population in general and urban population in particular is growing in a faster way.

The contribution of the transport sector to the economy is higher than the proportion of the expenditure being used to improve and maintain the sector. According to a Report of Asian Development Bank (2007), real gross domestic product (GDP) growth since 1990 has been consistently high, averaging 5.8 percentage yearly. In the financial year 2002, the road sector accounted for slightly less than 3percentage of total government expenditure and contributed about 15.5 percentage of revenues. Thus, the road sector generated a large fiscal surplus. The share of the transport sector in total GDP increased from 5.7percentage in 1999-2000 to 6.4percentage in 2004-2005. However, the share of the transport sector in public expenditure increased only from 3.2percentage to 4.2percentage during the same period, indicating the inadequacy of public spending. Roads. Road transport is the dominant mode, accounting for 65percentage of freight movement and 80percentage of passenger traffic rail transport accounts for much of the rest. The road network is divided into three categories: (i) the primary system of national highways, serving interstate long-distance traffic; (ii) the secondary system, consisting of state highways and major district roads carrying mainly intrastate traffic; and (iii) the tertiary system, comprising other district roads and rural roads. The Indian Railways owns and operates one of the largest rail networks in the world, covering more than 63,140 route km. Passenger traffic, in terms of passenger-km carried, increased from 66 billion in 1950-1951 to 541 billion in 2004-2005 (average annual growth rate of 4percentage), while freight traffic (in terms of net ton-km) increased from 44 billion to 384 billion during the same period (average annual growth rate of 4percentage). However, Indian Railways has been unable to compete consistently with other modes of traffic. During the last 5 decades, the share of railways in the freight traffic market fell from 89percentage to around 40percentage, and its share in the passenger traffic market dropped from 80 percentage to 20 percentage. 16 . 
Indeed, the significance of urban transport in India plays a major role in the reduction of poverty. Services and manufacturing industries particularly concentrate around major urban areas, and require efficient and reliable urban transport systems to move workers and connect production facilities to the logistics chain. In this regard due to the growth of IT sector in Bangalore, there has been an ongoing infrastructure investment in urban roads.

With this background the present paper seeks to examine the growth and development of transport sector in Karnataka with special reference to Bangalore. For the convenient the present paper has been divided into the following:

1. Air transport in Karnataka

2. The working of road transportation in Karnataka

3. The performance of BMTC

4. The working of metro rail

The transport facility plays an important factor in improving the GDP growth. NTDPC (National Transport Development Policy Committee) has estimated the GDP growth rate as 6. 9percentagefor $12^{\text {th }}$ Five Year Plan, 8percentage for $13^{\text {th }}$ Five Year Plan and 8.5 percentage for the $14^{\text {th }}$ Five Year Plan and 9percentage for $15^{\text {th }}$ Five Year Plan. The following table shows the data on the transport system in India since 1950-51 and the deeper analysis shows that rail and road transport system dominate in our country.

Table 1: Growth of Transport System in India

\begin{tabular}{|l|l|l|l|l|}
\hline Transport System & Unit of Measurement & $1950-51$ & $1970-71$ & $2000-01$ \\
\hline Railway Transport & Route Length (Km) & 53,600 & 59.800 & 62,900 \\
\cline { 2 - 5 } & $\begin{array}{l}\text { Freight traffic originating (million } \\
\text { tones) }\end{array}$ & 93 & 196 & 492 \\
\hline Road TRasport & Road Length (000 km.) & 400 & 915 & 3420 \\
\cline { 2 - 5 } & No. of goods vehicle (000) & 82 & 343 & 2680 \\
\hline Shipping & $\begin{array}{l}\text { Overseas shipping (million tonnes) } \\
\text { (GRT) }\end{array}$ & 0.2 & 2.2 & 7.0 \\
\hline Civil Aviation & No of passengers (lakhs) & & 26 & 87 \\
\hline
\end{tabular}

\section{AN OUTLINE FRAMEWORK OF AIR TRANSPORT:}

As per the IATA (International Air Transport Association), India will become the third largest aviation market in the world in terms of passengers by 2026. Furthermore, the IATA also expects the air passengers to grow at a compound average growth rate (CAGR) of 3.7 per cent to double from 3.8 billion air passengers in 2016 to 7.2 billion air passengers by 2035.India's air cargo is estimated to grow at 9 percent over the next few years, according to $\mathrm{Mr}$ Ashok Gajapathi Raju, Minister for Civil Aviation, Government of India.India has become the world's fastest growing domestic travel market for the 22nd time in a row, recording a 26.6 per cent year-on-year growth in January 2017, according to the IATA. According to CAPA (Centre for Asia Pacific Aviation) domestic air traffic is expected to grow 25 percent and cross 130 million in financial year 2017-18. The number of departures from India increased 20 per cent year-on-year to touch 131 million in 2016, according to the data by the IATA. CAPA estimates that India's airlines reported a combined profit of US\$ 122 million in fiscal 2016 (Media reports, 2017-18).

Bengaluru being the 'IT (Information Technology) capital' of India, the air traffic to this city have International flights operating from their airports i.e. Kempegowda International Airport with 9 domestic airlines and 19 international airlines. It includes Lufthansa, British Airways, Air France, Singapore Airlines and Malaysia Airlines. Within India there are 50 destinations.

\section{THE WORKING OF ROAD TRANSPORTATION IN KARNATAKA}

The road transport is much more use than the air transport as common people cannot afford the air transport and the number is also less compare to road transport. The road transport is easily accessible than the air transport. The National Sample Survey Office (NSSO) carries out an annual survey of household expenditure on service 
and durable goods in India. As per the details of expenditure on transport, buses are the most preferred mode of transport in both rural and urban India, followed by auto rickshaws.

The public bus transport in Karnataka is managed by the Karnataka State Road Transport Corporation (KSRTC). It was set up in 1961 with the objective of providing adequate, efficient, economic and properly coordinated road transport services.The growth and development of Karnataka public bus transport is given in details below.

\section{GROWTH AND DEVELOPMENT OF KSRTC}

The growth of vehicles has been much faster than that of the population. The number of registered vehicles increased from 55 million in 2001 to 142 million by 2011, with a currently-estimated 195.6 million in 2016 . Seventy-five per cent of these registered vehicles $(147$ million) are motorcycles. Furthermore, the physical infrastructure has not been able to keep pace with the growth in demand. The urban road length has increased from $252,001 \mathrm{~km}$ in 2001 to $411,840 \mathrm{~km}$ by 2011 . In the last decade registered vehicles per million population has increased by 219 percentage while urban road infrastructure per million only increased by 124 percentage.

KSRTC (Karnataka State Road Transport Corporation) has its corporate office at Bangalore. Presently, it covers seventeen Districts (Bangalore Urban, Bangalore Rural, Ramanagar, Kolar, Chickballapur, Tumkur, Chitradurga, Davanagere, Shivamogga, Mangalore, Udupi, Chickmagalur, Hassan, Mysore, Mandya, Chamarajnagar, Coorg) in the State under its operational jurisdiction. It has totally 15 Divisions - 14 operating Divisions viz. Bangalore Central, Ramanagar, Tumkur, Kolar, Chickballapur, Mysore City, Mysore Rural, Mandya, Chamarajnagar, Hassan, Chickmagalur, Mangalore, Puttur, Davanagere and 1 bus station division viz., KBS.79 Depots, 2 Regional Workshops, 1 Central Training Institute, 2 Regional Training Institutes, 1 Printing Press and 1 Hospital.

As at the end of 31-03-1997, the Corporation operated its services in 19 Divisions - 18 Divisions operating mofussil services and 1 Division operating city services of Bangalore. It had 108 Depots, 2 Regional Work Shops and a Central Office at Bangalore. There were 281 permanent and 11 temporary bus stations with 337 wayside shelters and 1009 pick-up shelters. The total number of employees deployed was 59033 and the staff ratio per schedule was 6.22. The total number of routes operated was 13273 with 9493 schedules, route length of 9.49 lakh Kms. and average daily scheduled kms of 27.95 lakh kms. Karnataka State Road Transport Corporation Provides so many Transport services to public namely Express, Rajahamsa, Karnataka Vaibhav etc. Table 1 briefly presents the services provide by of Karnataka State Road Transport Corporation (KSRTC).

Table: 1 Road Transport Services in Karnataka

\begin{tabular}{|c|c|c|c|c|}
\hline Sl.No & $\begin{array}{l}\text { Types } \\
\text { Services }\end{array}$ & Schedule Kms & $\begin{array}{l}\% \text { to total } \\
\text { Services }\end{array}$ & $\begin{array}{l}\% \text { to total } \\
\text { Operations }\end{array}$ \\
\hline 1 & Ordinary & 878178 & 31.86 & 30.62 \\
\hline 2 & Express & 1480959 & 53.73 & 51.64 \\
\hline 3 & Semi deluxe & 1888 & 0.07 & 0.07 \\
\hline 4 & Rajahamsa & 122661 & 4.45 & 4.28 \\
\hline 5 & Rajahamsa A/c & 1216 & 0.04 & 0.04 \\
\hline 6 & $\begin{array}{l}\text { Karnataka } \\
\text { Vaibhav }\end{array}$ & 17504 & 0.65 & 0.61 \\
\hline 7 & Corona & 2592 & 0.09 & 0.09 \\
\hline 8 & Corona Sleeper & 18822 & 0.68 & 0.66 \\
\hline 9 & Non-A/c Sleeper & 30041 & 1.09 & 1.05 \\
\hline 10 & Airavat(Volvo) & 99848 & 3.62 & 3.48 \\
\hline 11 & $\begin{array}{l}\text { Multi } \\
\text { Axle(Volvo) }\end{array}$ & 83596 & 3.03 & 2.91 \\
\hline 12 & Mercedez Benz & 4538 & 0.16 & 0.16 \\
\hline 13 & $\begin{array}{l}\text { Mercedez } \\
\text { Benz(Multi axle) }\end{array}$ & 11232 & 0.41 & 0.39 \\
\hline 14 & Bliss/Superia & 3236 & 0.12 & 0.11 \\
\hline Total & & 2756311 & 100.00 & 96.11 \\
\hline
\end{tabular}

(Source: Annual Administration Report 2014-15. Karnataka) 
Table 2 presents the Karnataka State Road Transport Corporation (KSRTC) provide services with respect towithin state and inter State Services (out of state).

Table 2: KSRTC and Interstate Services

\begin{tabular}{|l|l|l|l|l|r|r|}
\hline Sl.No & State & $\begin{array}{l}\text { No. of } \\
\text { Routes }\end{array}$ & $\begin{array}{l}\text { No of } \\
\text { Schedules }\end{array}$ & $\begin{array}{l}\text { Sch. kms } \\
\text { operated } \\
\text { within the } \\
\text { State }\end{array}$ & $\begin{array}{l}\text { Sch.kms } \\
\text { operated outside } \\
\text { the State }\end{array}$ & $\begin{array}{l}\text { Total } \\
\text { Schedule kms }\end{array}$ \\
\hline 1 & Maharashtra & 23 & 66 & 35030 & 13718 & 48748 \\
\hline 2 & $\begin{array}{l}\text { Andhra } \\
\text { Pradesh }\end{array}$ & 148 & 422 & 119958 & 88387 & 208345 \\
\hline 3 & Tamilnadu & 150 & 410 & 83744 & 96762 & 180506 \\
\hline 4 & Kerala & 65 & 166 & 27440 & 29936 & 57376 \\
\hline 5 & Goa & 8 & 20 & 8146 & 1702 & 9848 \\
\hline 6 & Pondicherry & 2 & 6 & 280 & 2168 & 2448 \\
\hline & Total & 396 & 1090 & 274598 & 232673 & 507271 \\
\hline
\end{tabular}

(Source: Annual Administration Report, KSRTC, Karnataka, 2014-15)

\section{THE PERFORMANCE OF BANGALORE METRO POLITAN TRNASPORT CORPORATION}

BMTC came in to existence as a consequence of bifurcation of Karnataka State Road Transport Corporation KSRTC in August 1997. BMTC has six major bus stations in Bangalore. Apart from these, it also has about 27 minor terminus. It has 37 depots spread all over Bangalore (Depot 1 closed for Shantinagar bus stand construction; 2 others also closed because of Traffic and Transit Management Centre - TTMC construction) out of which 34 are operational. BMTC aims to build 6 more depots on the city outskirts.

BMTC operates more than 4,850 buses in 5,810 schedules covering 12.53 lakh service kilometers carrying about 47 lakh passengers per day. As an organization which is realizing a good profit, it has given employment to more than 35,000 people. Bangalore Metropolitan Transport Corporation (BMTC) is enjoying the distinction of best performing mass transport system in India. It also has received laurels and appreciations from the Central and State governments.

Table 3: BMTC's Physical Performance at a Glance

\begin{tabular}{|c|c|c|c|c|c|c|c|c|c|}
\hline \multicolumn{7}{|c|}{ Physical Performance } & \multirow[b]{2}{*}{ 2014-15 } & \multirow[b]{2}{*}{$\begin{array}{l}2015- \\
16\end{array}$} & \multirow[b]{2}{*}{$\begin{array}{l}\text { 2016- } \\
17\end{array}$} \\
\hline Parameters & $\begin{array}{l}\text { 2008- } \\
09\end{array}$ & $\begin{array}{l}2009- \\
10\end{array}$ & $\begin{array}{l}2010- \\
11\end{array}$ & 2011-12 & 2012-13 & 2013-14 & & & \\
\hline Depots & 30 & 33 & 35 & 37 & 39 & 39 & 40 & 40 & 43 \\
\hline Buses added & 949 & 1218 & 58 & 385 & 549 & 838 & 197 & 0 & 101 \\
\hline Buses scrapped & 294 & 664 & 40 & 299 & 268 & 492 & 450 & 120 & 343 \\
\hline Buses held & 5542 & 6093 & 6111 & 6162 & 6431 & 6775 & 6522 & 6401 & 6161 \\
\hline Cancellation \% & 2.8 & 2.4 & 2.5 & 3.3 & 5.4 & 4.8 & 8.4 & 10.7 & 14.0 \\
\hline Diesel mileage & 4.37 & 4.11 & 4.01 & 3.97 & 3.84 & 3.82 & 3.79 & 3.76 & 3.74 \\
\hline Breakdowns & 2761 & 2204 & 1865 & 2396 & 3488 & 3521 & 2754 & 2570 & 2462 \\
\hline Accidents & 637 & 565 & 556 & 485 & 378 & 370 & 388 & 388 & 299 \\
\hline
\end{tabular}

Source: BMTC, Bangalore

The table 3 makes clear that the number of depot from 2008-9 to 2016-17 is found in an increasing trend whereas break downs and number of accidents are decreased from 2008-9 to 2016-17. This proves that there is a significant development in physical performance. 
Table 4: BMTC's Five Year at a Glance

\begin{tabular}{|l|l|l|l|l|l|}
\hline \multicolumn{7}{|l|}{ Financial Performance (in RS or Crore) } \\
\hline Parameters & $\mathbf{2 0 0 8 - 0 9}$ & $\mathbf{2 0 0 9 - 1 0}$ & $\mathbf{2 0 1 0 - 2 0 1 1}$ & $\mathbf{2 0 1 1 - 1 2}$ & $\mathbf{2 0 1 2 - 1 3}$ \\
\hline Traffic revenue & 907.49 & 1012.29 & 1211.23 & 1386.24 & 1527.18 \\
\hline Other revenue & 93.12 & 119.42 & 118.10 & 116.83 & 116.06 \\
\hline Gross revenue & 1000.62 & 1131.71 & 1329.34 & 1503.07 & 1643.25 \\
\hline Cost of Operation & 945.44 & 1066.58 & 1278.99 & 1481.66 & 1715.86 \\
\hline $\begin{array}{l}\text { Profit on traffic } \\
\text { revenue }\end{array}$ & -22.32 & -35.66 & -38.80 & -65.49 & -188.67 \\
\hline $\begin{array}{l}\text { Profit on gross } \\
\text { revenue }\end{array}$ & 55.17 & 65.12 & 50.34 & 21.41 & -72.61 \\
\hline Earning per km (Rs) & 22.34 & 22.91 & 26.44 & 29.78 & 32.92 \\
\hline Cost per km (Rs) & 23.27 & 24.14 & 27.92 & 31.82 & 36.99 \\
\hline \multicolumn{7}{|l|}{ Source: BMTC, Bangalore } \\
\hline
\end{tabular}

The year 2012-13 witnessed the Bangalore Metropolitan Transport Corporation (BMTC) losing its recognition as the lone urban public transport entity earning profits, after it posted a loss Rs. 147 crore. In June 2016 Bengaluru Metropolitan Transport Corporation (BMTC) became the first city in India to launch the Axis Bank BMTC Smart Card - an open loop EMV contactless smartcard.

Table 5: Financial Performance of BMTC from 2012-13 to 2016-17

\begin{tabular}{|l|l|l|l|l|l|}
\hline Parameter & $\mathbf{2 0 1 2 - 1 3}$ & $\mathbf{2 0 1 3 - 1 4}$ & $\mathbf{2 0 1 4 - 1 5}$ & $\mathbf{2 0 1 5 - 1 6}$ & $\mathbf{2 0 1 6 - 1 7}$ \\
\hline Effective Kms (Lakh) & 4638.38 & 4795.90 & 4708.56 & 4469.82 & 4205.20 \\
(\% Growth) & $(-0.4)$ & $(3.4)$ & $(-1.8)$ & $(-5.1)$ & $(-5.9)$ \\
\hline Traffic Revenue (Lakh) & 151600.16 & 176557.33 & 199411.06 & 19180.62 & 177047.15 \\
(\% Growth) & $(9.4)$ & $(16.5)$ & $(12.9)$ & $(-3.8)$ & $(-7.7)$ \\
\hline Gross Revenue (Lakh) & 166045.58 & 201394.23 & 225684.43 & 220748.39 & 210610.41 \\
(\% Growth) & $(10.5)$ & $(21.3)$ & $(12.1)$ & $(-2.2)$ & $(-4.6)$ \\
\hline Cost of Operation (Lakh) & 180841.03 & 216153.14 & 232174.81 & 219375.73 & 236701.42 \\
(\% Increase) & $(22.1)$ & $(19.5)$ & $(7.4)$ & $(-5.5)$ & $(7.9)$ \\
\hline Profit/Loss on Traffic Revenue (Lakh) & -23448.91 & -39595.78 & -32763.75 & -27573.11 & -59654.27 \\
\hline Profit/Loss on Gross Revenue (Lakh) & -14795.45 & -14758.15 & -6490.38 & 1372.66 & -26091.01 \\
\hline Margin on Traffic Revenue (in paise) & -630.4 & -825.6 & -695.8 & -616.9 & -1418.6 \\
\hline Margin on Gross Revenue (in paise) & -319.0 & -307.7 & -137.8 & 30.7 & -620.4 \\
\hline
\end{tabular}

Source: BMTC, Bangalore

\section{THE WORKING OF INDIAN RAILWAYS}

The Indian Railways is facing the toughest challenge in recent times. It has become acutely aware of this fact and is trying to face it as bravely as possible. The Railways is fully owned by the Government of India. It had a separate Budget till recently. "The Railways moves 23 million passengers a day in 1,261 passenger trains, for this purpose, every day. It has a network of 7,112 railway stations. Thus, Indian Railways is one of the world's largest networks comprising of 115,000 track $\mathrm{km}$ over a route of $67,312 \mathrm{~km}$. The Railways earned a total of 16,379 crore from all segments of traffic, including but only 44,283 crore from the passenger traffic in 2015-16. The Railways has a fixed target of earning 55,000 crore from the passenger segment - an increase of more than 15 percentage from the previous year. On the freight segment, the Railways earned 109,207 crore in the year 2015-16. It has fixed a target of earning 117,933 crore in the year 2016-17, i.e. an increase of about 8percentage (Thapar, 2017).

The total length of rail track in Karnataka is $3089 \mathrm{~km}$ (Indian Investment Centre.2017). For a long time after independence, the railway network in the state was under the Southern and Western railway zones which were headquartered at Chennai and Mumbai respectively. The South Western Zone, headquartered at Hubballi was created in 2003 thus fulfilling a long-standing demand of the state. Several parts of the state now come under this zone with the remaining being under Southern Railways. 


\section{THE EMERGENCE OF METRO TRAIN}

Many Indian cities are exploring the option of implementing metro rail networks after the success of the Delhi Metro. According to The Wikipedia, 2017, the Ministry of Urban Development (MOUD) estimates that there is approximately $316 \mathrm{~km}$ of metro lines currently in operation and more than $500 \mathrm{~km}$ of metro lines under construction across the country. This includes metro/mono rail systems promoted by state governments and private bodies. Namma Metro is serving the Bangalore city. It is currently the second longest operational metro network in India after Delhi Metro Rail (The Times of India, 2016). On the other hand, Namma Metro ranked the 83rd largest metro system in terms of length and 79th largest metro network in terms of number of operating stations in the world. It also contains the first underground metro line in South India (The Times of India, 2016). The metro network consists of two colour-coded lines, with a total length of 42.3 kilometers serving 41 stations. The system has a mix of underground, at-grade, and elevated stations using standard-gauge tracks. The metro has an average daily ridership of 315,000 passengers. Namma Metro was the second rail transport system in India to use $750 \mathrm{~V}$ DC third rail traction, the first is Kolkata Metro. Namma Metro is being built in phases. Currently, as of 18 June 2017 the entire portion of Phase 1 has been completed and is in operation.

Phase 1 missed nine deadlines, and its cost was revised four times. The original estimated cost of Phase 1 of the Namma Metro was 6,395 crore (US\$1.0 billion) when the project was approved in 2006. The expansion of the length of Phase 1 from $33 \mathrm{~km}$ to $42.3 \mathrm{~km}$ increased the total cost to 8,158 crore (US $\$ 1.3$ billion). Delays caused further escalations in the project cost. The cost escalated to 11,609 crore (US $\$ 1.8$ billion) in 2011 , and 13,845 crore (US $\$ 2.2$ billion) in 2015. The final cost to build Phase 1 was estimated at $14,405.01$ crore (US $\$ 2.2$ billion) (The Economic Times, 2017). Land acquisition for Phase 1 of the project cost 2,500 crore (US\$390 million) (The New Indian Express, 2016). The Central and State Government funded 58.91percentage of the total project cost. The remaining 41.09percentage was secured through loans from domestic and foreign financial institutions (The Economic Times, 2017).

On 3 January 2012, the Karnataka government approved a budget of 27,000 crore (US\$4.2 billion) for Phase 2 of Namma Metro project (IBN, 2012). Phase 2 is estimated to cost 26,405 crore (US\$4.1 billion). Land acquisition is expected to cost 5,000 crore (US\$780 million) (The New Indian Express, 2016). The Central and State Governments will fund around 15,000 crore of the project cost (Lalitha, 2017). The State and Central Governments will bear 30percentage and 20percentage of the total project cost of Phase 2 respectively. The remaining amount will be obtained through senior term loans (Deccan Herald, 2012). The BMRCL is permitted to raise up to 9,000 crore through loans (Lalitha, 2017).

During the first month, since the opening of Reach I, about 1,325,000 people traveled by the metro (The Times of India 2011). On average, 41,390 people took the train every day, while the average daily revenue was 667,262 . The BMRC earned a revenue of 2.1 crore(US $\$ 330,000)$ in its first month of operation (IBN, 2012). In the first six months of operation, average ridership went down to 24,968. The BMRC earned a total of 6.6 crore (US\$1.0 million) during the same period (Bangalore DNA, 2012). Namma Metro posted a profit of 41 lakh (US\$64,000) after almost one year of operating Reach I. BMRCL estimates that nearly 80 lakh passengers travelled on the system, in its first year of operations (Bangalore DNA, 2012)..

Table 6 shows the annual ridership and revenue of the Namma Metro Bangalore since its inception (The Hindu, 2016).

Table 6: Namma Metro - Bangalore Annual Ridership

\begin{tabular}{|l|l|l|}
\hline Year & Passengers & Revenue (crore) \\
\hline $2011-12$ & $4,166,000$ & 6.17 crore \\
\hline $2012-13$ & $6,636,000$ & 8.70 crore \\
\hline $2013-14$ & $7,255,000$ & 9.86 crore \\
\hline $2014-15$ & $11,400,000$ & 17.83 crore \\
\hline $2015-16$ & $16,800,000$ & 28.28 crore \\
\hline
\end{tabular}




\section{CONCLUSION}

Thus transport system in Karnataka has developed systematically. The facts and figures mentioned above have clearly revealed the best performance in the system. BMTC (Bangalore Metropolitan Transport Corporation) is no exception to this. Prior to metro rail, it is the BMTC which play a pivotal role in managing the urban population movement in and around Bangalore. Thus BMTC play a key role in the local transport without which the city would have to face lot of inconvenient to the public. The same was experienced by the public whenever bundh was called in the city. The recent launch of Metro Rail is a successful quick and faster mode of transport which was opposed in the initial stage, now appreciating it by everyone.

\section{References}

[1] Bangalore DNA, 2012."Joyrides in Bangalore Metro are over - Bangalore - DNA". Daily News and Analysis. Retrieved 25 July 2012.

[2] Bangalore DNA, 2012. "Bangalore Metro posts Rs 41 lakh profit in first year". Daily News and Analysis 18 October. Retrieved 18 October 2012.

[3] The Times of India 2011. "13.25 lakh rode the Metro". . 25 November 2011.

[4] IBN, 2012."Namma Metro gains momentum - South India - Bangalore - ibnlive". Ibnlive.in.com. Retrieved 3 January 2012.

[5] IBN, 2012."Admin approval for Namma Metro Phase 2 - South India - Karnataka - ibnlive". Ibnlive.in.com. Retrieved 6 March2012.

[6] Lalitha, S. 2017. The New Indian Express (6 February). "European Bank's Rs 3.7k crore fillip for Metro Phase-II". . Retrieved 10 February 2017.

[7] Deccan Herald, 2012. Bangalore, 17 Oct 2012, DHNS: (17 October 2012). "Centre's nod awaited to extend Metro to Bengaluru Intl Airport", Bangalore. Retrieved 4 March 2013.

[8] The Economics Times, 2017. "Cost and \& time overrun marks Bengaluru metro phase-I". Retrieved 9 March 2017.

[9] The New Indian Express, 2016. "Metro June Deadline Stands, But With Rider". The New Indian Express. Retrieved 27 April 2016.

[10] The Times of India, 2016. "South India's second underground Metro launch on April 29". Retrieved 26 April 2016.

[11] Wekipedia, 2017. Namma Metro. https://en.wikipedia.org/wiki/Namma_Metro. Retrieved on $8^{\text {th }}$ September, 2017.

[12] The Hindu, 2016. "Metro to complete 5 years of operations". The Hindu. October, 20. Retrieved on 8/5/2017.

[13] Indian Investment Centre.2017.Statistics related to transportation in Karnataka is providedby "Karnataka". Online webpage of Government of India. Retrieved 6.5.2007.

[14] Thapar, 2017. Current Status and Vision of Rail Sector in India. EXIM India Newsletter, New Year Special Supplement, Mumbai.

[15] Media Reports, Press Releases, Press Information Bureau, Directorate General of Civil Aviation (DGCA), Airports Authority of India (AAI), Union Budget 2017-18.

[16] Asian Development Bank 2007. Transport Sector in India. Focusing on results. Sector Assistance Programme valuation. Retrieved from http://www.oecd.org/derec/adb/39066399.pdf.

[17] BMTC, 2017. Performance indicator. Retrieved from http://www.mybmtc.com/en/performance-indicator on 22/09/2017. 